\title{
Article \\ Federalists and the Beginnings of the Council of Europe: Converting Institutions and Opinion to Supranationality (1949-1951)
}

\section{Bertrand Vayssière}

check for updates

Citation: Vayssière, B. Federalists and the Beginnings of the Council of Europe: Converting Institutions and Opinion to Supranationality

(1949-1951). Histories 2022, 2, 1-14. https://doi.org/10.3390/

histories2010001

Received: 4 October 2021

Accepted: 22 November 2021

Published: 24 December 2021

Publisher's Note: MDPI stays neutral with regard to jurisdictional claims in published maps and institutional affiliations.

Copyright: (C) 2021 by the author. Licensee MDPI, Basel, Switzerland. This article is an open access article distributed under the terms and conditions of the Creative Commons Attribution (CC BY) license (https:/ / creativecommons.org/licenses/by/ $4.0 /)$.
Department of History, University of Toulouse 2 Jean Jaurès, 31100 Toulouse, France; bertrand.vayssiere@orange.fr

\begin{abstract}
In 1949, it seemed that Western governments were ready to accept some delegation of sovereignty, which met the ambitions of increasingly well-organised Europeanists. One of the most ambitious advances was the proposal for a European Assembly, which could have heralded the beginning of an integration process. However, on this point, as on many others, there was not total agreement between the unionists and the federalists: for some, the Assembly was simply a co-operation structure, while others thought it should be a constituent body. The federalists—who had been united since December 1946 within the European Union of Federalists (EUF), which claimed to have no fewer than 150,000 members-were very demanding. After the adoption of the Statute of the Council of Europe on 5 May 1949, the EUF Central Committee approved a "motion on the Consultative Assembly" in which it openly demanded the drafting of a federal pact that would lead to real European power. Faced with the modest intergovernmental status of the Council of Europe, the EUF proposed that the Assembly of this Council should be transformed from a "consultative" to a "constituent" assembly, which amounted to condemning any kind of conciliatory attitude. Therefore, the constituent path was becoming more and more important within the federalist organisation: it was now a matter of pressing, without restraint, for the triumph of ideals freed from initial reluctance, in the most diverse forums. The most important of these remained the Council of Europe, which was, in the eyes of the federalists, an institution that could be improved. Defending an integrated Europe, the federalists called for the creation of a democratic power on the scale of the challenges of the time, which seemed to them to exceed that of the nation states. To achieve this, they defended a "political" vision of integration, of which the Council of Europe could be the spearhead. It is this struggle, which took place at a time when the construction of Europe seems to be based on a simple but firm act of will, that this article will examine.
\end{abstract}

Keywords: federalism; European constitution; council of Europe; European council of vigilance; European union of federalists

\section{Introduction}

Three years after the end of the war, Western governments seemed ready to make major concessions to the Europeanists in response to the various demands expressed at the end of the Hague Congress (7-10 May 1948) ${ }^{1}$ [1-5]. Of these, the proposal for a European Assembly seemed the boldest because it touched at the heart of the political sovereignty of each state. The main goal was to create a genuine European democracy (albeit limited to the West) in a context that fostered enthusiasm for the project: states that still seemed weak shortly after the war would be obliged to find solutions through greater co-operation while the growing threat to the East suggested a need for urgent action. In this sense, the Council of Europe was the first European organisation to have a parliamentary body and the objective of closer union between members was enshrined in its Statute. However, it must be noted that the Council of Europe system is a two-tier one, with the intergovernmental element-the Committee of Ministers-taking precedence as an executive body over the 
parliamentary element-the Consultative Assembly (a name that in this respect is quite revealing). However, on the issue of the future powers of the Assembly, as on many other points, the pro-Europeans were not in total agreement: some (the "unionists") favoured a simple organ of co-operation, while others (the "federalists") wanted the Assembly to be a constituent body. The latter, who had been united since December 1946 within the European Union of Federalists (EUF), which claimed to have no fewer than 150,000 activists, were very insistent. For them, the necessary "driving force" for the establishment of European democracy seemed to be ruled out by the monopoly exercised by statesmen within the framework of a Europe of nations. For this reason, the federalists rejected institutions they believed reproduced the classic model of national parliamentarianism in order to replace it with a model that was more acceptable to other stakeholders, the only model capable of "interposing the newest and most advanced ideas" (Fernand Dehousse) ${ }^{2}$ [6]. In many respects, the Council of Europe may indeed appear disappointing. Established by the Treaty of London, this international institution with a legal personality recognised in public international law aims to ensure the strengthening of democracy and the rule of law in Europe by means of legal standards in the fields of human rights protection. However, British reluctance had resulted in the body becoming an intergovernmental body rather than the supranational body federalists had hoped for. In the end, the executive Committee of Ministers dampened the ardour of the Parliamentary Assembly, which had been reduced to being a talking shop that lacked any leverage over the realities of the European debate. It was therefore a case of focusing their energy on giving the Assembly the highest possible visibility by organising large-scale demonstrations around it.

Convinced of the destiny of an integrated Europe, the federalists imagined a supranational democratic political structure in which legislative power would have a central role. In contrast to the functional approach envisaged by the Schuman Plan, the idea was to defend a "political" Europe by giving substance to the still vague notion of "European parliamentarism". In this article, we will look at how this struggle was conducted in the early days of the Council of Europe; a struggle between the hopes raised by its creation and the radicalisation that the Cold War soon brought to the process of European construction.

\section{A Strong Political Ambition}

The context of the late 1940s must be taken into account in order to understand the state of mind of the federalists, halfway between euphoria and doubts. On the positive side, we can underline the existence of unwavering support from the Americans, who had just confirmed their commitment to the construction of Europe, in fact Western Europe, by signing the Atlantic Pact (4 April 1949), responding to the call from the Europeans with the Brussels Pact of 17 March 1948. The Council of Europe was one of the consequences of this process of rapprochement, in which European integration became a decisive argument: it constituted the political part of a triptych that began with the economy with the Marshall Plan and continued at the diplomatic level with the Brussels Pact. Of course, the Council of Europe was not a political forum for parliamentarians, but rather a classic international organisation because of the British will, with the Labour government putting the brakes on the integration process. This attitude, which was confirmed by the publication the following year of a manifesto opposing this process ${ }^{3}$, was an element of context which obviously upset the federalists.

Caught between enthusiasm and reticence, the federalists nevertheless launched a pressure campaign using the Council of Europe as a sounding board. Thus, after the adoption of the Statute of this institution on 5 May 1949, the Central Committee of the EUF approved a "motion on the Consultative Assembly" 4 in which it openly called for the drafting of a Federal Pact to create a genuine seat of European power. Faced with the modest intergovernmental status of the Council of Europe, the EUF proposed that its Assembly should be transformed from a "consultative" body to a "constituent" one, which was tantamount to condemning any kind of conciliatory attitude. This radical demand contrasted with the much more modest one that the International Executive Committee of 
the European Movement had presented to the Ministers of Foreign Affairs on 9 May, in which only a few minor requests were made ${ }^{5}$. This moderation was realistic, with most members of the Committee believing that Britain would oppose any radical demands ${ }^{6}$, just as the previous month it had rejected Jean Monnet's proposals to merge the British and French economies ${ }^{7}$ [7]. On the other hand, within the EUF, the constituent path was becoming increasingly important: it was now a case of exerting unrestrained pressure in as many forums as possible in order to get rid of the initial reluctance and enable their ideals to triumph. The most important of these remained the Council of Europe, which the federalists saw as an institution that could be improved.

The differences between the EUF and its more moderate partners in the European Movement (EM) became apparent at the latter's first congress, which was held in Brussels on 25 February 1949, showing that not everyone in the Europeanist camp was satisfied. The unionists were pleased because the EM was largely inspired by the memorandum sent on 18 August 1948 by the Coordinating Committee of European Movements. This memorandum was drawn up by Paul Ramadier, who took charge of the institutional commission set up at the Hague Congress. It was a step back from the political resolution of The Hague-particularly with regard to Article 3, which called for the transfer of certain sovereign rights of States to the Assembly of the Council of Europe-as there was no longer any question of giving the latter "any legislative or executive power" which confined it to a consultative role. However, there was some progress in certain areas, such as cultural exchanges, the Charter of Human Rights and the European Court of Justice ${ }^{8}$. The federalists were still confident that "a decisive step" had been taken, from which "the European federalist idea would be transferred to the governmental level" 9 . However, the initial hope that a Constituent Assembly would be set up on a European scale soon gave way to disappointment, inasmuch as the planned European assembly no longer had constituent powers and could be compared to a mere study group. The main sticking point was of course the European Assembly. The new president of the Central Committee, Henri Frenay, stated that they had "no ambition to set up a European Commonwealth based on fragile contracts" 10 [8,9] and underlined the differences between the federalists he represented, and "those who are Europeans for fear of danger", i.e., those who would be satisfied with a defensive Europe and basic co-operation. The era of half-measures seemed to be over, which foreshadowed a difficult relationship with other Europeanist movements. Similarly, differences of opinion were emerging over the composition of the Council of Europe: the federalists thought it should include non-parliamentarians as well as members of parliament ${ }^{11}$, which was only partially reflected in the recommendations adopted by the Brussels meeting ${ }^{12}$.

However, the federalists were divided on the constitutional issue from the outset. The Italian Altiero Spinelli, who spearheaded the EUF, pushed for it to become the priority, in the spirit of the Ventotene Manifesto, which he had written in 1941, and which gave him greater prestige among his peers ${ }^{13}$ [10]. He was given the opportunity to do so when he was asked to write a report on the strategy the movement should follow for 1949. This report, entitled "Theses for the elaboration of a policy for the EUF" ${ }^{14}$, was presented to the Executive Committee on 25 March 1949. This document emphasised the need for a new political line "conscious of the goal to be achieved, capable of assessing the current situation in Europe, and based on intelligent tactics and adequate organisation" 15 . The key term in the report is the "Federal Pact", the aim of which was to lead all the states towards the creation of a European executive, clearly disassociating itself from the struggle led by the other European movements. In it, the Council of Europe is described as a "shadow without a body" ${ }^{16}$. Thus, we see that some federalists did not hesitate to publicly criticise an institution that seems, even before it was born, to have been very fragile.

However, this was not the definitive strategy, since on 17 June 1949 the Central Committee of the EUF, under the leadership of the Dutchman Henri Brugmans, drafted a more conciliatory public declaration ${ }^{17}$ that regarded the Statute of the Council of Europe 
of 5 May as "the first political realisation of the European idea" in accordance with the demands of the Congress of The Hague, and recognised the work and importance of the European Movement. The election of Paul-Henri Spaak to the presidency of the Assembly was also welcomed as an encouraging sign. However, Brugmans' tone was subsequently more brusque as the declaration went on to list the Council of Europe's weaknesseswhich included the rule of unanimity, the restriction of subjects to be debated by the Assembly, budgetary limitations and the weakness of its recommendations-and called for the establishment of a "Federal Pact" deemed necessary to give the Assembly sufficient powers. Thus, both wings of the EUF could be seen to be satisfied: Spinelli's pet idea of the Federal Pact was retained while the text that proposed it resembled a compromise of which Henri Brugmans was the main architect.

\section{Corridor Politics and Constitutional Claims}

The first session of the Consultative Assembly, which lasted for a month, opened in Strasbourg on 10 August 1949. Most of the participants remembered it as a happy day ${ }^{18}$ [11-13], when everything seemed possible. Those who participated in this first session wanted to give the Council of Europe a political role, with a General Affairs Committee being set up in response to the opening agenda, which stipulated the "consideration of any necessary changes in the political structure of Europe". The basic role of any parliament in a democratic system is to be able to set its own agenda and not fall under the supervision of the Committee of Ministers; however, this was an audacious position that was only supported by a fraction of Assembly members. The Europeanists' expectations were very high, and they even exerted "physical" pressure on members of the assembly, inaugurating a veritable strategy of "institutional harassment" ${ }^{19}$ [14]. As Henri Brugmans recalled, "the galleries on the first floor [of the building where the discussions were held] served as grandstands for 'observers', which included us. But we were not just observing. Whenever we thought it would be useful, we would ask an usher to pass a message to one of our friends on the assembly" ${ }^{20}$ [15]. Indeed, the members of the EUF were forging multiple contacts with assembly members from different political backgrounds, including Germaine Peyroles of the Mouvement Républicain Populaire; the radical senator Pierre de Felice; Carlo Schmid of the Christian Democrats; the Italian socialist, Enzo Giacchero; and the conservative Henry Hopkinson and Harry Hynd of the Labour party ${ }^{21}$, all of whom were members of one of the federalist groups belonging to the EUF. This "corridor politics" was so embarrassing to some assembly members that, during one session, Labour MP Hugh Dalton shouted: "People outside this House are trying to influence us. This is incompatible with the dignity of elected representatives!" ${ }^{22}$ [16] Was this a result of pressure from the federalist observers? The fact remains that the first resolutions to be adopted seemed to go their way. Of the many discussions held during this first session of the Council of Europe, the amendment proposed on 5 September by British Labour MP Ronald Mackay and French Socialist representative André Philip on institutional structures is particularly noteworthy. This amendment states that "the aim of the Council of Europe is the creation of a European political authority with limited functions but real powers" ${ }^{23}$ [17]. It was approved by a unanimous vote ( 88 votes) and seemed to presage a federal structure for the future. This vote was accompanied by a recommendation on human rights (September 1949) that met the wishes of the many supporters of European integration, a recommendation which would form the basis of the "European Convention for the Protection of Human Rights and Fundamental Freedoms", which would be signed by the governments on 4 November 1950.

The federalists' intentions are best understood by analysing their "request for the elaboration of a Federal Pact" 24 (formulated on 31 October 1949) which was to be presented to the Consultative Assembly of the Council of Europe and contained all the legal provisions expected of a federal organisation.

The very brief preamble marks the whole of the proposed work as urgent, reminding readers that this initiative was the only means to "prevent the definitive decline of our civilisation". 
The following points then set out what had thus far been achieved towards the construction of Europe, but which had failed or not gone far enough, namely, the Organisation for European Cooperation/OEEC (considered a failure), European defence, the constitution of a genuine German state, the establishment of a decent "standard of living", and the aims of a genuine Council of Europe. Their request is then specified: the setting up of a Federal Pact that would "determine the respective competences of the European bodies and the national authorities", in the purest tradition of constitutional federalism. Finally, the urgency of making a decision is reaffirmed, even if it means allowing the "most willing states" to get involved in the undertaking (in which the principles of a two-speed Europe reappear) ${ }^{25}$.

The request thus underlines the importance given to the Council of Europe by the federalists. They saw it as signifying "the beginning of real organic co-operation between European nations, and the end of the illusory belief that Europe could unite without creating supranational political structures" ${ }^{26}$. In its resolution of 24 and 26 September 1949, the Central Committee of the EUF had already demonstrated that the unilateral action of the British had been accomplished "without taking into account the requirements of the de facto interdependence of European currencies", and that it contributed to the "persistent survival of economic nationalism" 27.

However, although the federalists seem to have shown a real desire to discuss Europe's political structures in the Assembly (which as a new forum was already establishing itself), we can agree with Paul-Henri Spaak, its first president, that the solution they proposed did not necessarily meet with unanimous approval. In his view, three tendencies were apparent from the outset: the convinced federalists (who were in a minority) the "prudent" who envisaged a slow, marked-out progression, and finally those who advocated a cautious alignment with the British position (the majority, which included Spaak) ${ }^{28}$. The highly regarded successes of the first session seemed to announce a promising future, which explains why the first reactions of the EUF were generally positive. The fight for a Council of Europe "inspired" by the federalists was therefore the means to harden the resolve of all those in favour of European political structures ${ }^{29}$, and this was not an isolated position. The federalists' demands were really in line with those of the various Western socialist parties, many of whose members were affiliated to the large number of Europeanist movements that multiplied after the war. The parliamentary culture of these parties inclined them to favour the Council of Europe, with its fairly confident vision of future international relations where the "European bloc" could play a role as a third way between the United States and the USSR. For example, in the summer of 1949, the European Manifesto of the Section Française de l'Internationale Ouvrière proclaimed the desire to establish a Federation of Free Peoples based on the election of a European Assembly elected by universal suffrage. It can be assumed that this Assembly would be an emanation of the Council of Europe. Others were more sceptical, such as the newspaper Le Monde, which on 2 November 1949 gave a very broad account of the new federalist strategy and saw the mistake as being a tactical one: "But is the Consultative Assembly of the Council of Europe really shot through, as $\mathrm{Mr}$ Henri Frenay asserts, with a current opposed to timidity and the sterility of purely technical tasks?" 30 In other words, was there any chance of successful action through the Council of Europe? Doubts were even instilled in the Political Resolution of the Central Committee of the EUF dated 22 April 1950, which took stock of the first session of the Council of Europe and identified three specific leanings:

- The disappointment caused by the classic model of co-operation, which kept "the outdated system of national sovereignties intact", and the hope of arriving at a system that would make it possible to obtain "a European political authority with limited functions but real powers".

- $\quad$ The urgent need for action given specific problems (such as in Trieste and Saarland) as well as more general ones (namely, a divided Germany), but in general to oppose the "totalitarian offensive", i.e., the Soviet threat, which made itself most sharply felt in Berlin. 
- $\quad$ The need to set up a free and independent European entity, even if it was not an integral one ("an initial federal nucleus") ${ }^{31}$.

The federalists therefore still had hopes for the Council of Europe, but still made it clear that it was no longer in its interests to frustrate their efforts, as evidenced by a standard letter sent by Henri Frenay on 28 July 1950 to all delegates of the Council of Europe on the eve of the opening of their second session ${ }^{32}$.

These precautions did not, however, undermine the confidence shown by those federalists who were convinced of the good will of European public opinion, as was demonstrated in their view by the results of various surveys, in particular the Eric Stern survey of 23,000 people in Western Europe commissioned by the European Movement between January and June $1950^{33}$, which gave very favourable responses to the European Union in each of the countries surveyed. Fighting for Europe was therefore tantamount to appropriating all this good will and demonstrating how far behind the states were in this respect. It was this that the EUF wanted to prove to the representatives at the Council of Europe by putting its weight behind the campaign for a Federal Pact. And it is true that this campaign gained satisfactory results, particularly in Italy. Its repercussions were such that, on 6 June 1950, the Senate adopted an agenda pushing for the Council of Europe to take charge of European unification, joining the Chamber of Deputies which had taken the same position a few months before ${ }^{34}$. The support of part of the Italian political world was confirmed at the closing event of the campaign at the Palazzo Sistina in Rome on 4 November when Alcide de Gasperi ${ }^{35}$, Carlo Sforza and other ministers signed the petition, which was presented to the Chamber of Deputies and the Senate the following day [18].

\section{The European Vigilance Council}

In order to amplify their demands, the federalists decided to set up an assembly of activists, politicians and representatives of Europe's "driving forces" to meet in Strasbourg, a few steps away from the official Council of Europe Assembly, with a view to the second session of the Council of Europe. They give their unofficial assembly the name "European Vigilance Council" or "Council of the Peoples of Europe", with the aim of making the parliamentarians sitting in the Consultative Assembly face up to their responsibilities.

The European Council of Vigilance (ECV), as the name suggests, was intended to represent the European vanguard. Its aim was to create a movement in favour of convening a Constituent Assembly and drawing up a Federal Pact, open only to those states willing to accept it; it also tried to ensure acceptance of the principle of simple majority voting in the Council of Ministers, which would itself become an "Assembly of States", no longer made up of Ministers of Foreign Affairs but of "Ministers for European Affairs". The goal was to demonstrate the popular side of this initiative, concerned about the democratic form that Europe should take. As Georges Izard (EUF) explained, "The ECV will sit in Strasbourg at the same time as the European Council. By its presence and the evidence of its debates, it intends to be the visible face of the Europe that is impatient to be born. This assembly can only draw its prestige from the support of the broad masses" ${ }^{36}$ [19].

A new discussion on European political authority presented by Guy Mollet at the second session of the Council of Europe in August 1950 was an opportunity for the most daring Assembly members - with the help of their federalist friends - to propose comprehensive reform. Consequently, the first meeting of the ECV was held in the Salle de 1'Orangerie in Strasbourg from 21 to 24 September 1950 at the initiative of the EUF and involving federalist representatives and members of other Europeanist organisations. Then on 2 October the "sponsors" of the ECV, Henri Frenay, André Voisin, André Philip (Socialist Movement for the United States of Europe) and Robert Bichet (New International Teams), met as the "International Organising Committee of the European Vigilance Council", chaired by Henri Frenay, and signed an appeal for European unity and the constitution of a federal government and parliament ${ }^{37}$. They were supported in their undertaking by newspapers such as Combat, Franc-Tireur and Le Figaro ${ }^{38}$ The precedent of the Schuman Plan showed 
that not all European states were ready to embark on this venture and that it would be much more effective to trigger action only in those countries that were a priori favourable (especially France, Italy and the FRG) ${ }^{39}$ and thus avoid the prevarication that hindered the Council of Europe. In doing so, Frenay saw the ECV's attempt as a last resort: if the Council of Europe remained deaf to his appeal, it would mean that this institution was impotent to advance European construction and other solutions would have to be chosen.

This appeal took the form of an ECV manifesto, drawn up on 30 September 1950 by the International Organising Committee ${ }^{40}$. The manifesto refers to the general disappointment at the meagre results of the Consultative Assembly of the Council of Europe and the need to create a Western entity capable of defending itself as soon as possible. The appeal to public opinion was fuelled by the prevailing fears about the Korean War and stressed the existence of a common destiny for peoples threatened by the same enemy. This theme is also found in a second appeal drawn up by the ECV a month later (28 October 1950): ${ }^{4}$ "Now, in 1950, all the peoples of Europe are in total solidarity for war or peace, for freedom or servitude, for annihilation or for new stages of progress" ${ }^{42}$. Even before that war, the possibility that the Assembly might participate in defence matters seemed to be moving forward, with the creation on 3 June of a Joint Committee composed of members of the Committee of Ministers and the Consultative Assembly to coordinate activities through periodic discussions on common problems. The federalists were aware of this provision, and, based on the context, wanted to see it implemented.

The ECV's action needed to be short and effective, which was why the EUF intended to prepare well and above all to plan well, in order to avoid things getting out of hand. The International Organising Committee of the European Vigilance Council seems to have given concrete expression to the dream of a "progressive cartel" peculiar to the Europeanist movement that had been formulated during the debates at the Congress in The Hague to oppose the unionist vision of a man like Churchill, who was considered too conservative. However, the EUF still retained the upper hand, as shown by the election of Henri Frenay as president of the Organising Committee. The ECV itself was to complete its work on 20 November 1950, with delegates who, by then, had to "as far as possible be invested with the confidence of the peoples they represent" as demonstrated through referenda, individual and collective signatures, demonstrations, etc. Thus constituted, the ECV was "a legitimate expression of European public opinion". It was "not in competition with the Assembly" and it reserved "the right to act in Strasbourg according to circumstances without excluding actions of a revolutionary nature" ${ }^{43}$. It should be noted that the most prestigious delegations to the ECV were the Italians (two senators, three deputies, three secretaries general of political parties, two trade union presidents) and the French (eight parliamentarians, three senators, several teachers, economic and trade union actors and some who were quite simply convinced federalists) ${ }^{44}$. There were 205 members of the ECV, including 56 Italians, 43 Germans, 40 French, 14 Belgians, 8 Saarlanders, 7 Luxembourgers, 6 Greeks, 5 British, 4 Irish and 3 Spaniards ${ }^{45}$. However, there were no more than 30 members of national parliaments among the 205 members of the ECV (13 of whom were French or Italian), which was an undeniable weakness.

This situation fed a form of hostility within the federalist ranks towards the "officials", who were accused of thinking only of preserving their role by those who considered themselves the only true militants who were close to the demands of the base. What is more, these militant federalists remained a minority, albeit an active one, in the Assembly. They could not achieve the hoped-for reform of the Council of Europe, a Council of Europe that was itself blocked by the veto of the British representative on the Committee of Ministers, and was in competition with the nascent Schuman Plan that was presented in May 1950.

For example, the Belgian Raymond Rifflet-an active member of the EUF and one of the main facilitators of the lobbying campaign on the Council of Europe-was well placed to make this kind of recrimination ${ }^{46}$, as he had approached many politicians in his country 
so that they could participate in the ECV with rather disappointing results. Jean Rey ${ }^{47}$, Paul-Henri Spaak and Étienne de La Vallée Poussin each in turn refused to take part in the venture (and the last two even criticised it strongly ${ }^{48}$ ), while others (such as the trade unionist Paul Finet) accepted the invitation, but laid down conditions that limited their commitment ${ }^{49}$. Most of the other elected representatives contacted either did not respond or brought up the need for a nihil obstat from their respective parties or trade unions (Piet Vermeylen, Gus Cool); some merely expressed their deep pessimism about the initiative (again Jean Rey, who confirmed his refusal) ${ }^{50}$. The federalists may have been satisfied with some of those who joined them, such as Charles Plisnier, who asked to be part of the Belgian delegation ${ }^{51}$, but most were free spirits who were not anointed by any major political grouping. The gap between the European Movement-represented by the most prominent politicians on the national chessboard-and the federalist militants (who were more inclined to direct action than the principles of the ECV presupposed) was widening. This can be seen in Rifflet's own account of a lunch he had with a number of figures at the beginning of October 1950, shortly before the Council of Vigilance began its action, at which he aimed to explain the goals of this new campaign. There was a full range of politicians present at this lunch since it included socialists (Paul-Henri Spaak, Georges Bohy, Victor Larock, Jean Drapier and Henri Rolin), Christian Democrats (Paul Struye, Frans Van Cauwelaert and Étienne de la Vallée Poussin), a liberal (Roger Motz) and trade unionists (Paul Finet of the Fédération Générale du Travail de Belgique and Gus Cool of the Confédération des Syndicats Chrétiens). The meal quickly turned into an indictment of the federalists, represented by Rifflet, who was told that the European Movement would never support this action. Étienne de la Vallée Poussin was particularly hostile. The same was true of Spaak: "Spaak then spoke on the same subject even more violently, strongly criticising the irresponsibility and lack of seriousness of the federalists who had launched into the air poorly studied proposals and whose position of 'everything now or nothing' stoked defeat. For example, he cited the direct election of members of the Strasbourg parliament, saying that at present the people do not know what it is about and asserting that this would be the best way to bring local partisan quarrels to the European table. He also accused us of failing to draw the peoples' attention to the sacrifices to be made and thus maintaining harmful illusions. He also stated that our attitude practically excluded the English and Scandinavians, which at best meant the constitution of a German Europe and perhaps abandonment by the Americans who were withdrawing into the Commonwealth" 52 .

Thus, the atmosphere in the federalist ranks was gradually changing as they became aware that their appeal was unlikely to be heard. It was in this context that the call for a European Constitution was presented by a delegation of ECV members to the president of the Consultative Assembly, Paul-Henri Spaak, at the end of the second session, with the aim of "making parliamentarians face up to their responsibilities" 53 [20]. However, it received a rather cold reception from the latter ${ }^{54}$. This appeal did not refer explicitly to the Council of Europe, preferring to mention the convening of a "European Constituent Assembly responsible for drawing up a draft Pact of Federal Union". It should be noted in passing that the Schuman Plan had, despite some reticence, raised many hopes, since the text appealed "particularly to France, which has in the past, and even recently, been able to take bold initiatives", alluding on this last point to the Pleven Plan ${ }^{55}$. In fact, the text left little leeway for the Council of Europe, whose weaknesses the ECV could no longer ignore. This impression became apparent during the debates themselves, especially after the statement by the British Under-Secretary of State for Foreign Affairs, Ernest Davies, on 13 November 1950, according to which the British government would not accept any change in the status of the Council of Europe ${ }^{56}$. However, the federalists still found it difficult to come to terms with British involvement. This can be seen in the letter André Voisin sent to the editorial staff of Le Monde after the publication of an article summarising the EUF's action in Strasbourg, in which the federalists were presented as being opposed to British policy. Voisin clarified that the federalists were simply asking for an acceleration of 
the construction of Europe, the formation of the famous "hard core" which Great Britain could join whenever it wished ${ }^{57}$. However, the article could not hide the bitterness of the man who first came up with the idea of the ECV. Despite a final symbolic demonstration by 5000 young people from the Young European Federalists in front of the Consultative Assembly of the Council of Europe on 24 November ${ }^{58}$, the campaign ended without much hope. Contrary to the expectations of the ECV, the Council of Europe did not commit itself to anything.

This turning point came at the same time as a change of direction for the socialists, hitherto in favour of the most radical reforms to establish a European democracy, of which the Council of Europe would have been the main instrument. Aware of the limits now placed on the idea of a true democracy at Community level, they were now supportive of a different route towards their ideal. The defection of the Labour Party (which in the summer of 1950 made no secret of its rejection of any European democracy), the systematic rejection of European planning proposals by the OEEC and the impotence of the Council of Europe led the socialists, like the federalists, to abandon a global approach to democracy for another, more realistic step towards integration. There was thus an imperceptible shift from a doctrinaire attitude to more co-operative behaviour (which can be seen, for example, in the socialist federalists' change of name in November 1948 from the Socialist Movement for the United States of Europe to the Movement for the Socialist United States of Europe).

The path now favoured by both the federalists and the more Europeanist socialists was that of functional and sectoral agreements limited to a few sectors without renouncing the political ambition to create a supranational high authority. It was through this more cautious approach that, over a longer period of time, democracy would be established.

\section{Follow-up to the European Council of Vigilance}

The European Council of Vigilance had called "for the democratic states of Europe, which are prepared to accept the principle of limiting their sovereignty-some of them having expressly provided for this in their constitutions-to undertake to sign without delay an international treaty convening, as soon as possible, a European Constituent Assembly responsible for drawing up a draft Pact of Federal Union" ${ }^{59}$. With this in mind, the appeal specified that the members of the ECV would convene a conference where they would present a draft European Constitution to be submitted to the European states.

This was at the heart of the Spinellian strategy, where the idea of a Constitution took precedence over everything else in terms of European integration. Bringing the latter to a successful conclusion was now only a question of approach and time. In fact, a certain level of radicalisation could be observed among the federalists, notably due to increasingly tense relations with the European Movement following a stormy meeting of the International Committee in Strasbourg (23 November 1950), where the four representatives of the EUF (Frenay, Josephy, Spinelli and Voisin) left the meeting room following an argument over the future role of the Council of Europe. Henri Frenay summed up the mounting disagreements that he saw as provoking the crisis, including the refusal of the European Movement to call for the creation of a supranational political authority (2 September 1949); the election of Spaak as president of the European Movement (in July 1950), giving him yet another role and thus making him both "the besieged and the assailant"; and the quarrels at the meetings in Brussels in May 1950 and in London in July of the same year over the aims to be pursued by the organisation. Frenay's main accusation was that the European Movement wanted to stifle its member organisations and was content with a rearguard action around the Council of Europe ${ }^{60}$. The immediate decision was made to freeze all relations until further notice ${ }^{61}$.

The conference planned by the European Vigilance Council met in Lugano from 18 to 20 April 1951 with 60 representatives from 11 countries. The EUF published the proceedings of this conference on convening a European Constituent Assembly, and in May 1951 sent them "to all European representatives and senators with an appeal asking them to commit to adopting the method of political action established by the Conference" 
62. This meeting in Lugano was preceded by considerable efforts to undermine it: never before had members of the EUF made such efforts to lobby the various political decisionmakers. The most effective lobbyist was, once again, Altiero Spinelli, who regularly sent memoranda to those at the highest level ${ }^{63}$. As for the text drawn up in Lugano, it was sent to nearly 4000 members of national parliaments, 601 of whom signed it, 181 of whom were French (107 deputies and 74 senators), 201 Italian (124 deputies and 77 senators), 38 Belgian (16 deputies and 22 senators), 96 German, 35 Luxembourger, and 50 Saarlander (the Dutch parliamentarians were unable to sign a political commitment). A press release was sent by the EUF on 29 May 1951 formalising the federalists' initiative for the European Federal Constituent Assembly ${ }^{64}$.

The precedent of the European Coal and Steel Community (ECSC) was to become recurrent in federalist discourse, which espoused its internal logic and respected its shape (the Europe of the Six). Monnet's approach was praised, France was seen as an inspirational force that had been sorely lacking up to this point and the federalists were happy to believe in other novel legal formulas that would enable the European mechanism to be revived. The federalists thus rushed into the breach, seeing a logical continuity between the ECSC project and that of wider and more political unity. It was no coincidence that they waited for the day the ECSC Treaty was signed in Paris (18 April 1951) to reveal their project for a European Constitution. The time had come for extreme decisions to be made, for active militancy rather than continuing to reinforce the doctrines of a federalism that was already thought to be mature enough for the fight ahead ${ }^{65}$.

On 25 February 1951, an Action Committee for a Constituent Assembly was set up, of which Spaak became president (Frenay was Secretary General), a sign of rapprochement with the EUF after the stormy relations at the end of $1950{ }^{66}$. According to the historian François-Xavier Rebattet, Paul-Henri Spaak's agreement to chair a committee marked by federalist ideas was a real "conversion" of a man who, a few months earlier, had rejected most federalist initiatives, and in particular the European Council of Vigilance. It is difficult to agree with such an assertion; knowing Spaak's complex personality, it seems that he had understood all the advantages of embracing a cause that would attract American money and that seemed to have the approval of public opinion ${ }^{67}$ [21].

\section{Conclusions}

The year 1951 thus corresponds to a change in the EUF's tactics: there was no longer any question of using the Council of Europe as a means of obtaining the adoption of the Federal Pact. The idea of a Constituent Assembly remained, but this was now outside the framework of the Strasbourg assembly ${ }^{68}$. Once again, it was Altiero Spinelli who won support, when he envisaged no longer relying on the Council of Europe and proposed an initial union between those states in favour of a European Constitution. The British defection, the timidity of the European Movement, and the debates about a European Defence Community (EDC) launched by the Pleven proposal, created a very favourable context for the discussion of a topic that was hitherto little known to the general public. The EUF could now see itself as the spearhead of a Europeanist struggle that had changed in nature, and that made less use of the term supranationality.

But if the federalists were carried along by such a current, they owed it above all to an extremely tense international context. Never had the Cold War been so intense and never had the sense of urgency felt by a frightened West been so much in tune with the ideal of a united Europe, for the federalist discourse openly agreed with the vicissitudes of East-West relations, making European unity no longer a hope, but a refuge. There was a certain level of continuity between this state of affairs and that of the previous period (minus the bad conscience) that reflected the evolution of a group no longer concerned with ethics, but with efficiency. Thus, the aim of a European Constituent Assembly, if it were to succeed, would represent the end of a process that could form the launch pad for an unprecedented "federal society" in line with the predictions made by Spinelli at Ventotene during the Second World War. In fact, everything seemed to be moving in the direction of 
the most radical vision of federalism: that of a supranational body-towards which the EDC proposal seemed to lead-while awaiting that of de Gasperi (at the end of 1951) to reflect on a real political formula for the emerging Europe, and which launched the debate around the "European Political Community". The actions of the ECV thus failed at the same time as the Council of Europe no longer appeared to be the ideal means of achieving a true supranational democracy, but this failure did not worry anyone in the federalist camp at the time. The federalists were taking advantage of the opportunity to turn away from the parliamentary route (which they thought had no future) and to embark on a "headlong rush" that nothing seemed to be able to thwart.

As for the Council of Europe, after a final unsuccessful attempt to reform it politically, resulting in the resignation of its president Paul-Henri Spaak on 11 December 1951, it can be said that attempts to make it a parliamentary structure failed. It would remain a "forum of Europe", capable of allowing a minimum of dialogue between a maximum of European countries, anxious to give Greater Europe some form of recognition, endorsed by the signing of fundamental conventions (the Human Rights Convention in 1950 and the European Cultural Convention in 1954), and the only body to reflect on a global form of identity (as shown by the very early acceptance of a flag later taken up by the Community authorities). In short, at the end of 1951, the turn towards a small Europe with a supranational character was taken, to the detriment of a large Europe that remained largely utopian, and would be intergovernmental in essence.

However, this did not mean that the Council of Europe was becoming an empty shell: it was simply no longer a possible vehicle for a European democracy worthy of the name. Nonetheless, it embodied the ideal, seeing its membership grow from 10 to 18 states between 1949 and 1965. Far from the political vicissitudes that sometimes accelerated and sometimes slowed down the ECSC and then the European Economic Community (EEC) (particularly under de Gaulle), it remains a forum for dialogue on all pan-European subjects such as justice, environment, health, education and local authorities, and (albeit in competition with other institutions including the EEC, the ECSC, the Western European Union and the European Free Trade Association) the only framework organisation that would, one day, bring Greater Europe together.

Funding: This research received no external funding.

Institutional Review Board Statement: Not applicable.

Informed Consent Statement: Not applicable.

Data Availability Statement: Not applicable.

Conflicts of Interest: The Author declare no conflict of interest.

\section{Notes}

1 Many books and articles have been written on the birth of European federalism, the beginnings of the Council of Europe and more generally on the first steps of the European integration process: see in particular Vayssière 2007; Guieu and Le Dréau 2009; Wassenberg 2013; Tulli, 2017; O'Connor 2014, pp. 58-72.

2 Speech by Fernand Dehousse to the plenary session of the European Vigilance Council, 21 November 1950, quoted in Cohen 2006, p. 122.

3 European Unity: a statement by the National Executive Committeee of the British Labour Party (June 1950), London, Labour Party, 1950, 15 p.

$4 \quad$ Lipgens and Loth 1991, pp. 80-88; “Motion on the Consultative Assembly”, Paris Executive Board, 4-5 May 1949, UEF-128, Historical Archives of the European Union (now HAEU), Florence.

5 "Observations on the Statute of the Council of Europe submitted to the Ministers of Foreign Affairs of the democratic countries of Europe", International Executive Committee, Paris, 9 May 1949, ME-622, HAEU.

6 Copy of a letter from Lord Layton to Mr. Duncan Sandys circulated at Lord Layton's request among the members of the International Executive Committee, 13 May 1949, ME-622, HAEU.

$7 \quad$ Monnet 1976, pp. 401-404. 
"Memorandum presented to the European governments by the International Committee of Movements for European Unity", 18 August 1948, Notes and Documentary Studies, No. 1081, pp. 11-12, confirmed by the Conclusions and Recommendations adopted at the inaugural session of the International Committee of the European Movement, Brussels, 25-28 February 1949, ME-107, HAEU.

9 Title of the editorial in the UEF Bulletin, No. 3 bis, 25 August 1948, UEF-245, HAEU. In this article, the enthusiasm is such that the redactors speak of "the path of achievement", and foresee the establishment of a Constituent Assembly by 1950.

Lipgens and Loth 1991, p. 80. The use of the British term in the French is not accidental, as Frenay refers to a speech given by Ernest Bevin on 15 September 1948, in which he suggested that the future assembly should proceed "on the same principle of association as in the Commonwealth", in Bossuat 1996, p. 98. Speech by Ms Josephy in plenary session, 28 February 1949, ME-107, HAEU.

In the final declaration concerning the composition of the future Council of Europe, three points concern parliamentarians, and only one concerns non-parliamentarians, "reserved for promoters of European action" (Churchill, for example?).

"Theses for the elaboration of a UEF policy", 25 March 1949, UEF-90, AHAEU.

Ibid., p. 1.

Ibid., p. 7. The strategy of the Pact is to "transform the Consultative Assembly into a Constituent Assembly, with the aim of developing a Federal Pact of the United States of Europe".

UEF Bulletin No. 3, June 1949, pp. 28-29, in Lipgens and Loth 1991, pp. 81-82.

See in particular Bonnefous 1950, p. 123; Spaak 1969; Gouzy 1968, p. 62.

Belot 2003, p. 557.

Brugmans 1993, p. 277.

Letter from Henri Frenay to the parliamentary correspondents of the UEF, 30 June 1950, UEF-135, HAEU.

Brugmans 1993, p. 277. Labour's Hugh Dalton had been rather uncompromising from the Liberation onwards and not very open to any Europeanist ideas whatsoever. See Bossuat 1996, p. 99 or du Réau 1996, p. 183.

This sentence, which was to become the slogan of the Council of Europe, was essentially the work of Ronald Mackay, developed after numerous interviews with various federalist parliamentarians, including Senator Pierre de Felice, Richard Mayne and John Pinder, in Mayne and Pinder 1990, p. 103. The same authors point out, however (p. 103), that this sentence is almost word for word the slogan chosen by Federal Union in July 1943, when Frances Josephy was its president, the same Josephy who served as interpreter in Strasbourg at Mackay. See Frances Josephy, “Obituary for Ronald Mackay”, World Affairs, 1960, n 249 a, p. 47.

Request for the drawing up of a Federal Pact, 31 October 1949, UEF-246 and WL-198, HAEU. One can also read the Report on the Federal Pact by Gabriel Badarau, 9 p., UEF-95, HAEU, in which the speaker defends the Pact in a very voluntarist tone.

"Theses for the elaboration of a UEF policy", 25 March 1949, UEF-90, HAEU.

"Petition for the drawing up of a Federal Pact", 31 October 1949, UEF-246 and WL-198, HAEU, p. 4.

"On the devaluation of the pound", Appendix No. 4 of the minutes of the UEF Central Committee, 24-26 September 1949, UEF-246, HAEU.

Spaak 1969, p. 33.

Letter from Henri Frenay to Duncan Sandys, Paris, 20 September 1949, annex n ${ }^{\circ} 3$ of the minutes of the UEF Central Committee of 24-26 September 1949, UEF-204, HAEU, p. 2.

“L'UEF propose à l'Assemblée de Strasbourg un Pacte fédéral de l'Occident”, Le Monde, 2 November 1949.

Minutes of the UEF Central Committee, 22 April 1950, UEF-, HAEU.

Letter to Parliamentary Delegates to Strasbourg, 28 July 1950, UEF-204, HAEU. Although the letter is signed by Henri Frenay, Vice-President of the European Movement, he begins it by saying: "It is on behalf of the European Union of Federalists that I address you...", p. 1.

European Movement, "Poll on Public Opinion on the Question of the European Union", WL-199, HAEU; Guglielmo Usellini, "About the Stern Poll on the Question of the European Union", 4 p., 15 May 1950, WL-199, HAEU.

Lipgens and Loth 1991, pp. 246-247.

De Gasperi's involvement in the petition campaign remained an excellent memory for Spinelli, who spoke of it 45 years later in an interview with RAI: "We then had de Gasperi's first declaration in our favour, because he also signed the petition and declared that the Italian government should accept this commitment and act accordingly [[...]....] This man, De Gasperi, who was basically a moderate, did it with a revolutionary spirit, triumphing over resistance in Italy, in Italian administrations, and in other countries", in Paolini 1988, p. 81.

Quoted in Greilsammer 1975, p. 63.

André Voisin, "How the idea of the European Council of Vigilance was born", Courrier de l'Europe, No. 10, October 1950. 
André. Voisin, Outline of the report on the European Vigilance Council to be presented to the 1950 International Congress of the European Union of Federalists, UEF-204, HAEU, p. 4.

Letter from Altiero Spinelli to Henri Frenay, 19 September 1950, UEF-13, HAEU. The author specifies however that a more homogeneous federalist body in France would be necessary.

Manifesto of the delegates of the European Vigilance Council to the French, 30 September 1950, UEF-204, HAEU, p. 1.

Manifesto of the delegates to the European Vigilance Council, 28 October 1950, UEF-204, HAEU, p. 1. In the archives in Florence, there are some messages of support and petitions sent by various people (teachers, SNCF inspectors) to the members of the European Vigilance Council, UEF-8, UEF-11, HAEU, which proves that the Council's action was not totally unknown to the general public.

Manifesto of the delegates to the European Vigilance Council, 28 October 1950, UEF-204, HAEU, p. 1.

André Voisin, Outline of the report on the European Vigilance Council to be presented to the 1950 International Congress of the European Union of Federalists, UEF-204, HAEU, p. 3.

International Organising Committee of the European Vigilance Council, General Document No. 1, 6 October 1950, 6 p., UEF-204, HAEU.

List of delegates to the European Vigilance Council established on 1 November 1950, 4 p., UEF-204, HAEU.

Raymond Rifflet, Lettre à Henri Frenay, 14 octobre 1950, farde n²4, Groupe d'études histoire de l’Europe contemporaine (GEHEC), Louvain-la-Neuve; Vayssière 2018.

Raymond Rifflet, Letter to Charles Baré, June 9, 1950, folder n²4, GEHEC, Louvain-la-Neuve.

Raymond Rifflet, Letter to Henri Frenay, Enrique Gironella, Albert Lohest and Charles Baré, p. 1, 11 October 1950, folder n²4, GEHEC, Louvain-la-Neuve.

Letter from Paul Finet to Raymond Rifflet, 16 October 1950, folder n²4, GEHEC, Louvain-la-Neuve.

Letter from Albert Lohest to Raymond Rifflet, October 23, 1950, folder n²4, GEHEC, Louvain-la-Neuve.

Letter from Maurice Lambilliotte to Raymond Rifflet, 25 October 1950, folder n ${ }^{24}$, GEHEC, Louvain-la-Neuve.

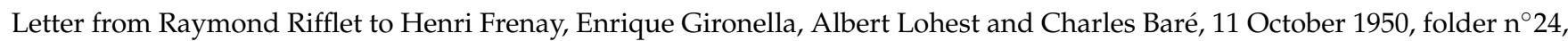
GEHEC, Louvain-la-Neuve, p. 1.

Brugmans 1970, p. 147.

Altiero Spinelli, “History and Perspectives of the European Federalist Movement”, p. 169-170.

Council of Europe, Strasbourg, 21-24 November 1950, UEF-204, HAEU.

Gouzy 1968, p. 69.

Letter from André Voisin to the Director of Le Monde, 5 October 1950, UEF-14, HAEU.

“5000 giovani a comizio davanti alla Maison d’Europe”, Europa Federata, III, 1 December 1950, n³6, p. 6.

"Parliamentarians of Free Europe, ask your governments for the convocation of the European Federal Constituent Assembly", UEF document, May 1951, UEF-204, HAEU, p. 1.

These reproaches are explained in detail in a letter from Henri Frenay to Fernand Dehousse, Paris, 26 November 1950, UEF-8, HAEU.

Letter from Guglielmo Usellini to Joseph Retinger, 21 December 1950, ME-404, HAEU, p. 2.

"Parliamentarians of Free Europe, ask your governments to convene the European Federal Constituent Assembly", UEF document, May 1951, UEF-204, HAEU, p. 1.

For example, a rather ambitious memorandum was sent to Alcide de Gasperi on 5 February 1951, UEF-97, HAEU. The same memorandum was sent a little later to René Pleven.

UEF Press Release, 29 May 1951, UEF-96, HAEU.

Brugmans 1970, p. 285.

Letter sent by the UEF to the citizens of the six Schuman Plan countries, containing the call for the European Constitution, UEF-97, HAEU.

According to Richard J. Aldrich, the amount allocated to the European Vigilance Council alone was $\$ 42,000$, (Durkee Report to ACUE Directors, July 1951, WBS/DDE), quoted in Aldrich 1995, p. 170.

Altiero Spinelli, “Bilancio dell'Assemblea”, Europa Federata, III, n³6, 1 December 1950, p. 11.

\section{References}

1. Vayssière, B. Vers une Europe Fédérale? les Espoirs et les Actions Fédéralistes au Sortir de la Seconde Guerre Mondiale; Peter Lang: Brussels, Belgium, 2007.

2. Guieu, J.-M.; Le Dréau, C. Le "Congrès de l'Europe" à La Haye (1948-2008); Peter Lang: Bruxelles, Belgium, 2009.

3. Wassenberg, B. Histoire du Conseil de l'Europe; Peter Lang: Brussels, Belgium, 2013.

4. Tulli, U. Un Parlamento per l'Europa. Il Parlamento Europeo e la Battaglia per la Sua Elezione (1948-1979); Mondadori: Milan, Italy, 2017. 
5. O'Connor, E. A Salutary Shock: The European Suffrage Movement and Democracy in the European Community, 1948-1973. J. Contemp. Eur. Res. 2014, 10, 58-73.

6. Cohen, A. De congrès en assemblées. La structuration de l'espace politique transnational européen au lendemain de la guerre. Polit. Eur. 2006, 1, 105-125.

7. Monnet, J. Mémoires; Fayard: Paris, France, 1976.

8. Lipgens, W.; Loth, W. Documents on the History of European Integration; Transnational Organizations of Political Parties and Pressure Groups in the Struggle for European Union; De Gruyter: Berlin, Germany; New York, NY, USA, 1991 ; Volume 4.

9. Bossuat, G. L'Europe des Français, 1943-1959. La IVe République aux Sources de l'Europe Communautaire; Publications de La Sorbonne: Paris, France, 1996.

10. Vayssière, B. Le Manifeste de Ventotene (1941): Acte de naissance du fédéralisme européen. Guerr. Mond. Confl. Contemp. 2009, 217, 69-76. [CrossRef]

11. Bonnefous, E. L'Idée Européenne et Sa Réalisation; Éditions du Grand Siècle: Paris, France, 1950.

12. Spaak, P.-H. Combats Inachevés; Fayard: Paris, France, 1969; Volume 2.

13. Gouzy, J.-P. Les Pionniers de l'Europe Communautaire; Centre de Recherches Européennes: Lausanne, Switzerland, 1968.

14. Belot, R.; Frenay, H. De la Résistance à L'Europe; Seuil: Paris, France, 2003.

15. Du Réau, E. L'Idée d'Europe au XXe Siècle; Complexe: Brussels, Belgium, 1996.

16. Brugmans, H. Á Travers le Siècle; Presses Interuniversitaires Européennes: Brussels, Belgium, 1993.

17. Mayne, R.; Pinder, J. Federal Union: The Pioneer; Macmillan: London, UK, 1990.

18. Greilsammer, A. Les Mouvements Fédéralistes en France de 1945 à 1974; Presses d'Europe: Paris, France, 1975.

19. Paolini, E. Altiero Spinelli. Appunti per Una Biografia; Il Mulino: Bologna, Italy, 1988.

20. Brugmans, H. The European Idea, 1920-1970; De Tempel: Bruges, Belgium, 1970.

21. Aldrich, R.J. European Integration: An American Intelligence Connection. In Building Postwar Europe, National Decision-Makers and European Institutions, 1948-1963; Deighton, A., Ed.; Saint Martin's Press: London, UK; New York, NY, USA, 1995. 